\title{
Interannual and spatial variability of maple syrup yield as related to climatic factors
}

Sugar maple syrup production is an important economic activity for eastern Canada and the northeastern United States. Since annual variations in syrup yield have been related to climate, there are concerns about the impacts of climatic change on the industry in the upcoming decades. Although the temporal variability of syrup yield has been studied for specific sites on different time scales or for large regions, a model capable of accounting for both temporal and regional differences in yield is still lacking. In the present study, we studied the factors responsible for interregional and interannual variability in maple syrup yield over the 2001-2012 period, by combining the data from 8 Quebec regions ( Canada) and 10 U.S. states. The resulting model explained $44.5 \%$ of the variability in yield. It includes the effect of climatic conditions that precede the sapflow season (variables from the previous growing season and winter), the effect of climatic conditions during the current sapflow season, and terms accounting for intercountry and temporal variability. Optimal conditions for maple syrup production appear to be spatially restricted by less favourable climate conditions occurring during the growing season in the north, and in the south, by the warmer winter and earlier spring conditions. This suggests that climate change may favor maple syrup production northwards, while southern regions are more likely to be negatively affected by adverse spring conditions. 
and

$11 *$ Corresponding author (e-mail: louis.duchesne@mrn.gouv.qc.ca)

12 Tel: (418) 643-7994 ext: 6537; Fax: (418) 643-2165

$14{ }^{1}$ Direction de la recherche forestière, Ministère Ministère des Forêts, de la Faune et des Parcs,

15 2700, rue Einstein, Québec, Québec G1P 3W8 Canada.

$16{ }^{2}$ Consortium sur la climatologie régionale et l'adaptation aux changements climatiques

17 (Ouranos), 550, rue Sherbrooke Ouest, Tour Ouest, 19e étage, Montréal, Québec H3A 1B9

18 Canada. 
Sugar maple (Acer saccharum Marsh.) is broadly distributed in North America,

21 throughout the northeastern United States and southeastern regions of Canada (Little, 1971). Due

22 to the exceptional sweetness of its sap, this species is commercially exploited for maple syrup

23 production. In 2011, the world production of maple syrup was estimated at 49.5 millions litres,

$2479 \%$ of which were produced in Canada, and $21 \%$ in the U.S. (FPAQ 2012).

The relation between the timing of the period of sapflow, syrup yield, and the fluctuation

of air temperatures around $0^{\circ} \mathrm{C}$ is intuitively known by producers; it has been observed and

27 characterised in scientific studies, including Marvin \& Erickson (1956), Plamondon (1977), and

Pothier (1995). However, the climatic conditions prevailing during the sapflow season are not the

only determinants of yield. Previous winter conditions, such as high mean January temperatures,

can also be negatively correlated to yield, possibly due to the importance of cold hardiness on sap

sugar content (Rock \& Spencer, 2001; Duchesne et al., 2009; Tyminski, 2011). Along with local

32 climatic conditions, many other factors can affect maple syrup yield, including physical tree

33 parameters (Blum, 1973), genetic characteristics (Kriebel, 1989), foliar chemistry (Leaf \&

34 Watterston, 1964), soil fertility (Watterston, Leaf \& Engelken, 1963) and sap extraction and

35 conversion methods (Morrow \& Gibbs, 1969). Although these factors can explain variations in

36 maple syrup yield between trees or sites, climate remains the main factor affecting annual yield

37 fluctuations, through its effect on sap flow fluxes, sugar concentration, or both (Marvin \&

38 Erickson, 1956; Cool, 1957; Pothier, 1995; Duchesne et al., 2009).

The importance of the maple syrup industry has increased considerably over the last

40 decades. Technological developments have improved efficiency and allowed individual farms to

41 exploit significantly more taps in their maple stands. Nevertheless, climate variability induces 
42 high year-to-year fluctuations in production volume, which often leave maple syrup producers

43 with low-yield years, during which the benefit-cost ratio is reduced.

44 Some recent studies suggest that the maple syrup industry may be significantly affected

45 by climate change. Duchesne et al. (2009) coupled the results of a regression model that linked

46 the annual yield of Quebec's industry to climate over a 22-year period with a dataset of future

47 climatic scenarios obtained from several global climate models driven by different scenarios of

$48 \quad \mathrm{CO}_{2}$ emissions. Their results indicate that maple syrup yield could experience a $15 \%$ decrease by

492050 and a $22 \%$ decrease by 2090 , compared to the 1984-2006 reference period. Nevertheless,

50 assuming that the variables included in the prediction model reveal a pattern of climatic

51 conditions that could occur earlier in the season, total maple syrup yield could be maintained at

52 its current level if the period of sap production was advanced by 12 days in 2050, and by 19 days

53 in 2090. From a simple model of sapflow potential based on biology and physics, Skinner,

54 DeGaetano \& Chabot (2010) reach similar conclusions for the U.S. industry; they predict that the

55 warmer winter temperatures expected for the twenty-first century will result in a decline in the

56 number of sapflow days, if the traditional sap collection schedules are maintained. They also

57 suggest that the number of sapflow days across the northeastern U.S. might be maintained if the

58 current sap collection schedule was adapted to occur 19 to 30 days earlier (depending on the

59 climate scenario used) by 2100 . Other impact assessment reports also highlight the potential

60 effects of climate warming on the maple syrup industry (Rock \& Spencer, 2001; Maclver et al.,

61 2006; Frumhoff et al., 2007).

62 Studies documenting the effect of climate on maple syrup yield are based on previously

63 established relationships between sapflow and the daily alternation of freezing and thawing

64 temperatures for specific sites (Maclver et al., 2006; Frumhoff et al., 2007; Skinner, DeGaetano

$65 \&$ Chabot, 2010), or on regression models linking variability in climate to the interannual average 
66 maple syrup yield at different regional scales (Rock \& Spencer, 2001; Duchesne et al., 2009;

67 Tyminski, 2011). Nevertheless, none of these studies document the simultaneous influence of

68 climate on maple syrup yield on both interannual and interregional variability. Such information

69 is a prerequisite for evaluation of the impact of climate change on the maple syrup industry over a

70 broad territory. For instance, a site effect could be due to average climatic conditions

71 (temperature and precipitation) that influence general growth conditions, and indirectly, syrup

72 yield. This effect cannot be ascertained by only looking at year-to-year yield variations at a given

73 site.

74 The main objective of the present study was to identify the factors responsible for 75 interregional and interannual variability in maple syrup yield in northeastern North America over 76 the 2001-2012 period. We combined the data from 8 Quebec regions and 10 U.S. states covering 77 a broad region in which mean annual temperature varies by $8.8{ }^{\circ} \mathrm{C}$. We hypothesized (1) that 78 interregional variations would be predicted by average regional climatic conditions, and (2) that

79 both interregional and interannual variations would be predicted by climatic variables. 


\section{Materials and methods}

81

82

83

84

\subsection{Maple syrup yield}

Annual maple syrup yields over the 2001-2012 period were compiled from the National Agricultural Statistics Service (USDA-NAAS, 2012) and the 2012 economic report of the Federation of Quebec Maple Syrup Producers (FPAQ, 2012). Average annual yield data for the 12-year period were available for 8 administrative regions in Québec and for 10 U.S. states (Figure 1), for a total of 216 individual years of production. Yield statistics were reported in U.S. gallons per tap for the U.S. industry and in pounds per tap for Quebec. Data were converted to metric values $\left(\mathrm{ml} \mathrm{tap}^{-1}\right)$ using conversion factors of 11.03 pounds per U.S. gallon and $344 \mathrm{ml}$ per pound (Agriculture and Agri-Food Canada, 2007).

\subsection{Meteorological Data.}

Daily precipitation and temperature were generated for each state or region using the BioSIM model (Régnière, 1996, Régnière and St-Amant, 2007). BioSIM was originally developed to simulate insect development at the regional scale as a function of time-series of weather data. It operates by matching the geo-referenced sources of weather data (120 monitoring stations including the last 30 years of data) to the specified location, and then adjusts the selected sources of weather data to the specified latitude, longitude, elevation, slope, and aspect. The correlation between estimated and measured values is generally over 98\% (Régnière and Bolstad, 1994).

Daily temperature and precipitation data were generated for each intersection point on a $25 \mathrm{~km} \mathrm{x}$ $25 \mathrm{~km}$ grid covering the study area within the overall distribution of sugar maple (Figure 1). Daily climate data were then averaged by state and region. 
We investigated the linear relationships between a set of selected climate variables and interregional and interannual maple syrup yield variability using a multiple regression model (1).

$$
Y_{i}=\beta_{0}+\beta_{1} x_{i 1}+\beta_{2} x_{i 2}+\ldots+\beta_{p} x_{i p}+\varepsilon_{i}
$$

106 where $x_{\mathrm{ij}}$ is the $i^{\text {th }}$ observation on the $j^{\text {th }}$ independent variable, $\beta_{0}$ the model intercept, $\beta$ 's the

107 model parameters, and $\varepsilon_{\mathrm{i}}$ the error term. Climate variables were chosen based on results of 108 previous studies, which identified the most influential climate variables for maple syrup 109 production (see introduction). We focussed our analysis mainly on variables characterizing daily

110 freeze-thaw events, winter hardiness, and climatic conditions that prevailed during the previous 111 growing season. The variables tested are listed in Table 1. In addition to these, time was also 112 tested to investigate potential annual trends in yield that might not be explained by climate (e.g. 113 yield improvements associated to technological developments, or yield decline due to 114 overtapping). Similarly, a potential difference between countries (Canada vs the U.S.) was also 115 assessed to take into account the possible effect of methodological differences in the acquisition 116 of yield statistics (e.g. weight vs volume measurements, survey protocols, etc.). All possible 117 regression models were tested with the RSQUARE procedure (SAS Institute, 2002) to determine 118 the maximum amount of variance in maple syrup yield that could be explained as a function of 119 climate variables. The final models were selected based on Mallow's Cp-statistic (Mallows, 120 1973) and Akaike's information criteria (Akaike, 1973). Multicollinearity among climate 121 variables of the selected models was tested using condition indexes and the variance inflection 122 factor, to verify that dependencies among variables did not affect the regression estimates 123 (Belsey, Kuh \& Welsch, 1980). Residuals were graphically checked to assess the tenability of the 
124 regression assumptions. Partial regression residual plots, factoring out the influence of other

125 covariables, were used to summarize the relationships between climate and maple syrup yield.

\section{3. Results}

1273.1 Variability in maple syrup yield from 2001 to 2012

128 Figure 2A shows the distribution of the individual observations of annual maple syrup 129 yield, which ranged from $314 \mathrm{ml} \mathrm{tap}^{-1}$ (Wisconsin in 2012) to $1306 \mathrm{ml} \mathrm{tap}^{-1}$ (Vermont in 2011),

130 for an overall average $\left( \pm 1\right.$ s.e.) of $740 \pm 11 \mathrm{ml} \mathrm{tap}^{-1}$. Mean annual yields ranged from $624 \pm$ $13120 \mathrm{ml} \mathrm{tap}^{-1}$ in 2001 to $951 \pm 31 \mathrm{ml} \mathrm{tap}^{-1}$ in 2011 (Figure 2B), while the regional yields varied from $132640 \pm 45 \mathrm{ml} \mathrm{tap}^{-1}$ in Pennsylvania (region 16) to $910 \pm 28 \mathrm{ml} \mathrm{tap}^{-1}$ in Vermont (region 10; Figure $1332 \mathrm{C})$.

\subsection{Air temperature and precipitation variability from 2001 to 2012}

For individual years and regions, mean annual temperature (Figure $3 \mathrm{~A}$ ) varied from $0.9{ }^{\circ} \mathrm{C}$

136 (Capitale-Nationale/Saguenay-Lac-St-Jean in 2004) to $12.3^{\circ} \mathrm{C}$ (Ohio in 2012), for an overall

137 average of $6.4 \pm 0.2^{\circ} \mathrm{C}$. Yearly averaged mean annual temperature over the entire study area 138 ranged from $5.4 \pm 0.6{ }^{\circ} \mathrm{C}$ in 2003 to $7.5 \pm 0.7{ }^{\circ} \mathrm{C}$ in 2012 (Figure 3B), while regional averages 139 over the whole period ranged from $2.2 \pm 0.3{ }^{\circ} \mathrm{C}$ for Capitale-Nationale/Saguenay-Lac-St-Jean to $140 \quad 11.0 \pm 0.2^{\circ} \mathrm{C}$ for Ohio (Figure $3 \mathrm{C}$ ).

141 Total precipitation ranged from $716 \mathrm{~mm}$ (Wisconsin in 2003) to $1751 \mathrm{~mm}$ (Connecticut in 2011), 142 with an overall average of $1138 \pm 14 \mathrm{~mm}$ (Figure 3A). Yearly averaged total precipitation over 143 the entire study area ranged from $928 \pm 15 \mathrm{~mm}$ in 2001 to $1327 \pm 59 \mathrm{~mm}$ in 2011 (Figure 3B).

144 Regional averages over the whole period ranged from $828 \pm 26 \mathrm{~mm}$ in the western edge of the 145 range in Wisconsin (region 12) to $1332 \pm 59 \mathrm{~mm}$ for Connecticut (region 17; Figure 3C). 
The best multiple linear regression model using regional averages of meteorological

148 variables, a time and a country effect, explained $44.5 \%$ of the variance in maple syrup yield

149 records (Figure 4) (2).

150

$$
\begin{gathered}
\hat{U}=-36792+17.9 \times \text { Years }_{i}+65.3 \times \text { Country }_{i}+0.26 \times G D D_{i}-0.18 \times P P T_{i} \\
\text { Yield } \\
-13.0 \times \text { MinT }_{i}+5.3 \times \text { FFT }_{i}-16.9 \times \text { MaxTFT }_{i}+48.5 \times \text { MeanTFT }_{i}+6.6 \times D O Y 75_{i}
\end{gathered}
$$

152 The climate variables include cumulative growing degree days (GDD, Figure 5C) and

153 precipitation during the previous growing season (PPT, Figure 5D), daily minimum temperature 154 (MinT, Figure 5E), frequency of spring freeze-thaw events (FFT, Figure 5F), maximum 155 (MaxTFT) and mean temperatures (MeanTFT) during the freeze-thaw events (Figure 5G, 5H), 156 and the day of year when the cumulative growing degree days reach 75 (DOY75, Figure 5I). A 157 portion of the variance that could not be explained by the climate variables was associated with 158 temporal (Years, Figure 5A) and regional effects (Country, Figure 5B). The country effect is 159 calculated based on a binary variable having the value of 1 for Canada and 2 for the U.S.

\section{4. Discussion}

\subsection{Maple syrup yield and average regional climate variability}

163 the mean regional climatic conditions within the study area, despite the strong south-north

164 gradient in average annual temperature (difference of $8.8^{\circ} \mathrm{C}$ between region 1 , Ohio, and 165 region 18, Capitale-Nationale/Saguenay-Lac-St-Jean). Similarly, the particularly dry 166 precipitation regimes (including winter precipitation) observed in Wisconsin (828 $\mathrm{mm} / \mathrm{yr}$, region 
167 12) and Michigan $(850 \mathrm{~mm} / \mathrm{yr}$, region 13) did not translate into a marked difference in maple

168 syrup yield for these regions. These observations suggest that variability in annual maple syrup

169 yield at the regional scale results from complex interactions with climate, and that the climate

170 gradient alone cannot explain variability over the studied territory. For instance, higher annual

171 average temperature in the southern portion of the study area may favor growth and vigor of

172 sugar maple trees, which could positively affect syrup yield. However, higher mean temperatures

173 could also result in less favorable springtime conditions, if temperatures are too high or if there

174 are fewer freeze-thaw cycles. Average climatic conditions may reflect different realities along the

175 gradients of mean annual temperature and precipitation observed over the studied territory. These

176 considerations are discussed below. A potential effect of the climatic gradient on yield might also

177 be obscured by regional variations in growth and vigor of maple trees, soil fertility, atmospheric

178 acid deposition, and sap extraction and conversion methods.

\subsection{Model of maple syrup yield}

A multiple regression model using regional averages of climate variables and the effects

181 of time and country explained $44.5 \%$ of the interannual and interregional variability in maple

182 syrup yield for 18 regions over the 12-year period $(\mathrm{n}=216)$. The Quebec and U.S. data are well

183 distributed within the range of predicted and observed values (Figure 4). The variance explained

184 by our model is comparable to that of Tyminski's (2011) climate model, which accounts for 44\%

185 of the interannual maple syrup yield variability observed in the state of New York over the 1916-

1862006 period. However, this is considerably less than the variance explained (84\%) by the model

187 of Duchesne et al. (2009) for the total yield in the province of Quebec over the 1985-2006 period,

188 for which the interregional variability was somehow buffered at the provincial level. The model

189 in the present study combines climate variables measured prior to the sapflow season (previous

190 growing season and winter) and during the sapflow season itself, as well as terms accounting for 
191 yield variations over time and between countries that cannot be explained by the climate 192 variables.

\section{4.2.1 Impacts of the previous growing season and winter conditions on yield}

194 Our model suggests that the maple syrup yield of a given sapflow season is significantly

195 affected by the climatic conditions prevailing during the previous growing season. Warmer and 196 drier conditions during a given growing season were associated to a higher yield during the 197 subsequent period of sapflow (Figure 5C, 5D). Maple syrup yield was much more sensitive to 198 temperature than to precipitation: a variation of 2105 cumulative growing degree days (from 1991506 to 3611 ) resulted in a yield variation of $545 \mathrm{ml} \mathrm{tap}^{-1}$, while a variation of $1034 \mathrm{~mm}$ in 200 precipitation (from 459 to $1493 \mathrm{~mm}$ ) was associated to a yield variation of only $183 \mathrm{ml} \mathrm{tap}^{-1}$ 201 during the subsequent sapflow period (Figure 5D). Warmer summer conditions are associated 202 with higher maple syrup yield (Figure 5C). Dendroclimatic studies have shown that warm 203 summer temperatures generally favour greater radial growth rates of sugar maple trees (Payette,

204 Fortin \& Morneau, 1996; Goldblum \& Rigg, 2005). Although there is no clear demonstration of a 205 causal link between sugar maple growth rate and maple syrup yield, a number of studies have 206 suggested positive relationships between sugar maple growth and sap sugar content, sapflow 207 amounts, or both. For example, Laing \& Howard (1990) showed a link between sap sugar content 208 and growth rate, and suggested an association between low competition pressure and greater sap 209 sweetness. In good agreement with this, Morrow (1955) reported that maple trees with large 210 crowns tended to produce more and sweeter sap than suppressed trees or those that were 211 subjected to competition. Morselli, Marvin, \& Lang (1978) observed that maples with sweeter

212 sap had larger xylem rays than did trees whose sap was less sweet. All of these observations 213 concur with our results and support the hypothesis that the previous growing season conditions 214 influence maple syrup yield, probably due to the positive influence of climate on tree growth and 
215 starch storage capacity (Tyminski, 2011). We presume that the weak and negative correlation

216 between precipitation levels during the previous growing season and maple syrup yield reflects

217 the negative impact of reduced photosynthetically active radiation on tree growth, as a result of

218 increased cloud cover (Goldblum \& Rigg, 2005).

219 Climate during the previous winter also affects yield. Winter cold hardiness accounts for a 220 large part of the spatial variability in maple syrup yield; the colder territories in the north are 221 favoured compared to those in the south (Figure 5E). A progression in daily minimum 222 temperature from -40.7 to $-13.6{ }^{\circ} \mathrm{C}$ resulted in a yield variation of $353 \mathrm{ml} \mathrm{tap}^{-1}$. In the New 223 England Regional Assessment Group report, Rock \& Spencer (2001) provide data showing a 224 moderate negative correlation between total U.S. syrup production and mean winter temperature 225 between 1916 and 1999. Duchesne et al. (2009) and Tyminski (2011) also observed that yearly 226 variations in maple syrup yield in the province of Québec and the state of New York were 227 negatively correlated to mean January temperatures. In various types of plant cells, sugar content 228 appears correlated to frost hardiness (Sakai, 1960). Sugar acts as a biological antifreeze in plants 229 (Sauter \& Van Cleve, 1991; Yuanyuan et al., 2009). The accumulation of soluble sugar in roots of 230 sugar maple trees is known to coincide with periods of lowest soil temperatures; this suggests that 231 winter temperature plays a decisive role in the sugar-starch-sugar cycle (Bertrand et al., 1999).

232 Freezing tolerance of plants can also be enhanced by a gradual exposure to low temperatures.

233 Soluble sugars play an important role in this process, known as cold acclimation (Yuanyuan et al., 234 2009). Consequently, we hypothesize that the negative correlation observed in our dataset 235 between maple syrup yield and daily minimum winter temperatures is the result of sugar maple 236 cold acclimation. 
Skinner, DeGaetano \& Chabot (2010) suggested that there was a well-established and

239 predictable relationship between maple sapflow and alternating freezing and thawing

240 temperatures. This conclusion is based on unpublished data from Eggleston and Chabot showing

241 that sapflow recorded over a 30-year period at the Uihlein Forest (Lake Placid, NY) occurred on

$24280 \%$ of the days when the minimum temperature fell below $-1.1{ }^{\circ} \mathrm{C}$ and maximum temperature

243 exceeded $2.2{ }^{\circ} \mathrm{C}$. Similarly, Plamondon (1977) reported that the daily minimum temperature and

244 the difference between the minimum and maximum temperatures were correlated with daily

245 sapflow in a one-year experiment, while Pothier (1995) reported that annual sap yield and sap

246 sugar concentration over a 15 -year record were strongly correlated to the number of days in

247 spring during which temperatures fluctuated around $0{ }^{\circ} \mathrm{C}$. On the other hand, Cool (1957) found

248 that daily maximum temperature was the only climatic factor significantly correlated with sap

249 flow, Kim and Leech (1985) found that maximum temperature was the most important climatic

250 factor explaining increases in daily sap flow over a 5-year period, and Marvin and Erickson

251 (1956) showed that freezing temperatures were not a necessary prerequisite for sapflow. In the

252 present study, both the frequency of freeze-thaw events and the mean temperature during these

253 events were positively related to maple syrup yield, while the maximum daily temperature over

254 the same period was negatively related to maple syrup yield (Figure 5F, 5G, 5H). The frequency

255 of freeze-thaw events and the associated temperatures appear to capture mainly interannual

256 variability in maple syrup yield. However, these variables explain much less spatial variability

257 than the climatic conditions prevailing during the previous growing season and winter.

258 Consequently, although previous studies have shown that sapflow was correlated with the

259 frequency of freeze-thaw events at a given site or for a given territory, our results suggest that this

260 variable alone does not capture the interregional variability in maple syrup yield. 
The day of year when the cumulative growing degree days reached 75 was strongly and

262 positively related to maple syrup yield, accounting for a large part of its spatial variability. A

263 variation of 75 days resulted in a yield variation of $493 \mathrm{ml} \mathrm{tap}^{-1}$ (Figure 5I). In the southern

264 portion of the study area, early spring conditions had a more negative impact on maple syrup

265 yield than did late spring conditions occuring in the north. High air temperatures not only induce

266 bud break and interrupt sweet sap flow, but also accelerate the physical plugging of the tap,

267 which is caused by the combined effects of a bacterial invasion and vessel blockage by 268 microorganisms, gummy substances, or both (Ching \& Mericle, 1960).

269

270

271

272

273

274

275

276

277

278

279

280

281

282

283

284

\subsubsection{Trend in time and intercountry differences}

Within the total explained variance (44.5\%), a portion was due to an increasing temporal trend in maple syrup yield $(7.7 \%)$ and to intercountry differences $(0.4 \%)$ which were not related to a concomitant trend in the selected climate variables. The increasing temporal trend in yield contrasts with observations by Duchesne et al. (2009) who noted no yield increase over time (1985-2006), despite the efforts invested by producers over recent decades to improve existing industrial infrastructures. Efficient collection systems, including plastic tubing (Koelling, Blum, \& Gibbs, 1968) and vacuum pumping (Blum \& Koelling, 1968) along with improved sanitation practices are known to increase total yield. These systems have gained in popularity over recent decades, with an expected positive effect on maple syrup yield. We also hypothesize that the increasing trend of maple syrup yield over time can be related to the addition of new, more productive taps. The number of exploited taps in Québec and the U.S. increased from 40.4 million in 2001 to 52.6 million in 2012 (Figure 6). Over the same period, the maple syrup yield increase (unexplained by the selected climate variables) was approximately $155 \mathrm{ml} \mathrm{tap}^{-1}$. This increase was significantly correlated to the number of exploited taps $(r=0.87, p<0.001)$.

84 When a tap is drilled into the tree, the wood tissues surrounding the tap become stained. Tapping 
285 into stained wood reduces sapflow (Smith, 1971). Some guides and regulations are now provided

286 to prevent overtapping, but many older sugarbushes may have been overtapped. Consequently,

287 producers often observe that newly tapped trees are generally more productive than trees that

288 have been tapped for many years. Not only can wood compartmentalization reduce the yield of

289 old taps, but more efficient, newly installed equipment may also contribute to increasing the yield

290 of new taps compared to older ones. The stability of the maple industry resulting from the

291 Quebec Federation of Maple Producers strategic reserve and the strengthening of the Canadian

292 dollar in comparison to the U.S. dollar may have contributed to stimulating expansion (additional

293 taps) and technological investment, thus increasing productivity.

We also observed that sugar maple yield on U.S. territory was, on average, slightly higher

$295\left(65 \mathrm{ml} \mathrm{tap}^{-1}\right)$ than in Quebec. Consequently, part of the interregional variability in maple syrup

296 yield might be explained by other factors, such as soil fertility, atmospheric acid deposition, sap

297 extraction and conversion methods, and sugarbush management. In addition, intercountry

298 comparisons were also affected by differences in survey procedures. For example, the unit of

299 measurement used by both countries (weight for Canada and volume for U.S.) requires a

300 conversion that may cause differences in the evaluation of sugar maple production. Consequently,

301 the differences reported between U.S. and Canada yields that are not related to climate should be 302 interpreted with caution.

\section{Conclusion}

The interregional and interannual variability in maple syrup yield were studied over the

305 entire range of the sugar maple syrup production zone in Quebec and the northeastern United

306 States. A large part of the variance in syrup yield was explained by climate, and more specifically

307 by the conditions prevailing during the previous growing season and the previous winter. The 
308 frequency of spring freeze-thaw events and temperature conditions during the sapflow period

309 explained a smaller part of the variability in syrup yield, mainly related to interannual variability

310 in yield, and were much less spatially discriminating. Within the climatic gradient present in the

311 study area, warmer growing seasons in the south were associated to higher maple syrup yields

312 (possibly due to a positive influence on tree growth), while in the north, higher yields were

313 associated to colder winters (probably related to increased frost hardiness) and later spring

314 conditions. Consequently, optimal conditions for maple syrup production appear to be spatially

315 restricted in the north by the less favourable climate conditions during the growing season, and in

316 the south, by the warmer winter and earlier spring conditions. These observations suggest that, at

317 the regional scale, annual maple syrup yield variability results from complex interactions with

318 climate. This variability cannot not be explained solely by the climate gradient over the territory

319 studied, nor by the frequency of freeze-thaw events that characterize a given season.

320 Consequently, climate change risk assessment for the maple syrup industries of northeastern

321 North America remains a challenge.

\section{Acknowledgment}

323 We would like to thank the anonymous reviewers and Timothy Perkins for their valuable

324 comments and suggestions to improve the quality of the paper. We are also grateful to Denise

325 Tousignant and Debra Christiansen Stowe for English editing.

\section{References}

327 Agriculture and Agri-Food Canada (2007) Canadian maple products: situation and trends 2006-

328 2007. 25 pp. Available at

329 http://www5.agr.gc.ca/resources/prod/doc/misb/hort $/$ sit $/ \mathrm{pdf} / \mathrm{maple} \mathrm{2006-07} \mathrm{e.pdf}($ accessed 8

330 April 2014). 
331 Akaike H. 1973. Information theory and an extension of the maximum likelihood principle. In:

332 Petrov BN \& Csaki F ed. International Symposium on Information Theory. Akademia Kiado,

333 Budapest, pp. 267-281.

334 Belsey DA, Kuh E, Welsch RE. 1980. Regression Diagnostics: Identifying Influential Data and

335 Sources of Collinearity. John Wiley \& Sons Inc., New York.

336 Bertrand A, Robitaille G, Nadeau P, Castonguay Y. 1999. Influence of ozone on cold acclimation

337 in sugar maple seedlings. Tree Physiology 19:527-534.

338 Blum BM. 1973. Relation of sap and sugar yields to physical characteristics of sugar maple trees.

339 Forest Science 19:175-179.

340 Blum BM, Koelling MR. 1968. Vacuum pumping increases sap yields from sugar maple trees.

341 U.S. Forest Service Research Paper NE-106.

342 Ching TM, Mericle LW. 1960. Some evidences of premature stoppage of sugar maple sap

343 production. Forest Science 6:270-275.

344 Cool BM. 1957. An investigation of the effect of some production techniques and weather factor

345 on maple sap and sugar yields in a central Michigan woodlot. Ph.D. Thesis. Mich. State Univ.

346 Duchesne L, Houle D, Coté MA, Logan T. 2009. Modelling the effect of climate on maple syrup

347 production in Québec, Canada. Forest Ecology and Management 258:2683-2689.

348 FPAQ, 2012. Fédération des producteurs acéricoles du Québec. Dossier économique 2012

349 [online]. Available at http://www.siropderable.ca/Afficher.aspx?page=92\&langue=fr (accessed 8 350 April 2014). 
351 Frumhoff PC, McCarthy JJ, Melillo JM, Moser SC, Wuebbles DJ. 2007. Confronting climate

352 change in the U.S. Northeast: science, impacts and solutions. Synthesis report of the Northeast

353 Climate Impacts Assessment (NECIA). Union of Concerned Scientists (UCS), Cambridge.

354 Available at $\quad$ http://www.climatechoices.org/assets/documents/climatechoices/confronting-

355 climate-change-in-the-u-s-northeast.pdf (accessed 8 April 2014).

356 Goldblum D, Rigg LS. 2005. Tree Growth Response to Climate Change at the Deciduous-Boreal

357 Forest Ecotone, Ontario, Canada. Canadian Journal of Forest Research 35:2709-2718.

358 Kim YT, Leech LH. 1985. Effects of climatic conditions on sap flow in sugar maple. Forestry 359 Chronicle 61:303-307.

360 Koelling M, Blum BM, Gibbs C. 1968. A summary and evaluation of research on the use of 361 plastic tubing in maple sap production. U.S. Forest Service Research Paper NE-116.

362 Kriebel HB. 1989. Genetic improvement of sugar maple for high sap sugar content. I. Clone

363 selection and seed orchard development. Canadian Journal of Forest Research 19:917-923.

364 Laing FL, Howard DB. 1990. Sap sweetness consistency vs. growth rates in young sugar maples.

365 1990. Northern Journal of Applied Forestry 7:5-9.

366 Leaf AL, Watterston KG. 1964. Chemical analysis of sugar maple sap and foliage as related to 367 sap and sugar yields. Forest Science 10:288-292.

368 Little EL Jr. 1971. Atlas of United States trees, volume 1, conifers and important hardwoods: U.S. 369 Department of Agriculture Miscellaneous Publication 1146, 9 p., 200 maps [online]. Available at 370 http://esp.cr.usgs.gov/data/little/ (accessed April 8 2014). 
371 Maclver DC, Karsh M, Comer N, Klaassen J, Auld H, Fenech A. 2006. Atmospheric influences

372 on the sugar maple industry of North America. Environment Canada, Adaptation and Impacts

373 Research Division, Occasional Paper 7. Available at

374 http://publications.gc.ca/collections/collection_2011/ec/En57-41-7-2006-eng.pdf (accessed April

$37582014)$.

376 Mallows CL. 1973. Some comment on Cp. Technometrics 8:661-675.

377 Marvin JW, Erickson RO. 1956. A Statistical Evaluation of Some of the Factors Responsible for

378 the Flow of Sap from the Sugar Maple. Plant Physiology 31:57-61.

379 Morrow RL. 1955. Influence of tree crowns on maple sap production. Cornell Agricultural

380 Experimental Station Bulletin 916:3-30.

381 Morrow RR, Gibbs CB. 1969. Northeastern Forest Experiment Station. U.S. Forest Service 382 Research Note NE-91.

383 Morselli MF, Marvin JW, Lang FM. 1978. Image-Analyzing Computer in Plant Science. More 384 and Larger Vascular Rays in Sugar Maples of High Sap and Sugar Yield. Canadian Journal of 385 Botany 56:983-986.

386 Payette S, Fortin MJ, Morneau C. 1996. The recent sugar maple decline in southern Quebec:

387 probable causes deduced from tree rings. Canadian Journal of Forest Research 26:1069-1078.

388 Plamondon A. 1977. Analyse préliminaire de quelques facteurs écologiques influençant la 389 production de la sève d'Acer saccharum. Naturaliste Canadien 104:127-134. 
390 Pothier D. 1995. Effets des coupes d'éclaircie et des variations climatiques interannuelles sur la

391 production et la teneur en sucre de la sève d'une érablière. Canadian Journal of Forest Research

$392 \quad 25: 1815-1820$.

393 Régnière J. 1996. Generalized approach to landscape-wide seasonal forecasting with

394 temperature-driven simulation models. Environmental Entomology 25:869-881.

395 Régnière J, Bolstad P. 1994. Statistical simulation of daily air temperature patterns eastern North

396 America to forecast seasonal events in insect pest management. Environmental Entomology 23:1368-

3971380.

398 Régnière J, St-Amant R. 2007. Stochastic simulation of daily air temperature and precipitation

399 from monthly normals in North America north of Mexico. International Journal of 400 Biometeorology 51:415-430.

401 Rock B, Spencer S. 2001. Case study 2: The Maple Sugar Industry. In Preparing for a changing

402 climate, the potential consequences of climate variability and change, New England regional

403 overview. U.S. Global Change Research Program. University of New Hampshire, Durham, pp

404 39-42. Available at http://www.climateimpacts.org/us-climate-assess-2000/regions/new-

405 england/NERAch5.pdf (accessed April 8 2014).

406 Sakai A. 1960. Relation of Sugar Content to Frost-Hardiness in Plants. Nature 185:698-699.

407 SAS Institute, SAS version 9. SAS Institute, Cary, NC, USA, 2002.

408 Sauter JJ, Van Cleve B. 1991. Biochemical and ultrastructural results during starch sugar

409 conversion in ray parenchyme cells of Populus during cold adaptation. Journal of Plant 410 Physiology 139:19-26. 
411 Skinner CB, DeGaetano AT, Chabot BF. 2010. Implications of twenty-first century climate

412 change on Northeastern United States maple syrup production: Impacts and adaptations. Climatic

413 Change 100:685-702.

414 Smith HC. 1971. Tapping near old tapholes in sugar maple trees. Research Note NE-126. Upper

415 Darby, PA: U.S. Department of Agriculture, Forest Service, Northeastern Forest Experiment

416 Station. 3p.

417 Tyminski WP Jr. 2011. The utility of using sugar maple tree-ring data to reconstruct maple syrup

418 production in New York. Ph.D. Thesis. University of North Carolina, Greensboro.

419 USDA-NAAS 2012. U.S. Department of Agriculture National Agricultural Statistics Service.

420 [online] Available at http://www.nass.usda.gov/Data_and_Statistics/index.asp (accessed 8 April 421 2014).

422 Watterston KG, Leaf AL, Engelken JH. 1963. Effect of N, P, and K fertilization on yield and

423 sugar content of sap of sugar maple trees. Soil Science Society of America Journal 27:236-238.

424 Yuanyuan M, Yali Z, Jiang L, Hongbo S. 2009. African Journal of Biotechnology 8:2004-2010. 


\section{Table 1 (on next page)}

Selected climate variables used to model yearly regional maple syrup yield. 
Table 1. Selected climate variables used to model yearly regional maple syrup yield.

\begin{tabular}{|c|c|c|c|}
\hline Variables & $\begin{array}{l}\text { Mea } \\
\mathrm{n} \\
\end{array}$ & Min. & Max. \\
\hline \multicolumn{4}{|l|}{ 1) Previous summer conditions } \\
\hline \multirow[t]{2}{*}{ Total heating degree days $>3{ }^{\circ} \mathrm{C}\left({ }^{\circ} \mathrm{C}\right)$} & 2398 & 150 & 3611 \\
\hline & & 6 & \\
\hline Maximum temperature $\left({ }^{\circ} \mathrm{C}\right)$ & 32 & 26 & 36 \\
\hline Total precipitation during days with mean temperature $>3{ }^{\circ} \mathrm{C}(\mathrm{mm})$ & 807 & 459 & 1493 \\
\hline \multicolumn{4}{|l|}{ 2) Previous winter conditions } \\
\hline Total cooling degree days $<-1{ }^{\circ} \mathrm{C}\left({ }^{\circ} \mathrm{C}\right)$ & 737 & 48 & 1776 \\
\hline Minimum temperature $\left({ }^{\circ} \mathrm{C}\right)$ & -26 & -41 & -14 \\
\hline Total precipitation during days with mean temperature $<-1{ }^{\circ} \mathrm{C}(\mathrm{mm})$ & 203 & 18 & 476 \\
\hline \multicolumn{4}{|l|}{ 3) Freeze-thaw events and spring conditions } \\
\hline Frequency of daily freeze-thaw events (days) & 32 & 12 & 56 \\
\hline Minimum temperature during the freeze-thaw events $\left({ }^{\circ} \mathrm{C}\right)$ & -13 & -7 & -24 \\
\hline Maximum temperature during the freeze-thaw events $\left({ }^{\circ} \mathrm{C}\right)$ & 16 & 10 & 24 \\
\hline Mean temperature during the freeze-thaw events $\left({ }^{\circ} \mathrm{C}\right)$ & 1.5 & 0.9 & 3.3 \\
\hline Mean daily temperature range during the freeze-thaw events $\left({ }^{\circ} \mathrm{C}\right)$ & 12 & 10 & 15 \\
\hline First day of year when total heating degree days reach 75 (DOY) & 110 & 68 & 143 \\
\hline Total precipitation during the freeze-thaw events $(\mathrm{mm})$ & 62 & 7 & 225 \\
\hline
\end{tabular}

Note: A daily freeze-thaw event was recorded when the minimum temperature fell below $-1{ }^{\circ} \mathrm{C}$ and the maximum temperature exceeded $3{ }^{\circ} \mathrm{C}$. 


\section{Figure 1}

Sugar maple distribution in northeastern North America along with the grouped administrative regions of Quebec (Canada) and American states with significant maple syrup production.

Fig 1. Sugar maple distribution in northeastern North America (Little 1971). The numbers correspond to the grouped administrative regions of Quebec (Canada) and American states with significant maple syrup production. 1: Capitale-Nationale/Saguenay-Lac-St-Jean; 2: Bas-St-Laurent-Gaspésie; 3: Centre-du-Québec/Mauricie; 4: Laurentides/Outaouais/AbitibiTémiscamingue; 5: Lanaudière/Laval/Montréal; 6: Chaudière-Appalaches; 7: Estrie; 8: Montérégie, 9: Maine, 10: Vermont, 11: New Hampshire, 12: Wisconsin, 13: Michigan, 14: New York, 15: Massachusetts, 16: Pennsylvania, 17: Connecticut, 18: Ohio. White dots represent the $25 \mathrm{~km} \times 25 \mathrm{~km}$ grid used to generate climate data. 


\section{Figure 2}

Quantile plot of maple syrup yield for the 216 observations, and mean maple syrup yield averaged by year and by region over the time period on the studied territory.

Fig 2. Quantile plot of maple syrup yield for the 216 observations (A), and mean maple syrup yield averaged by year $(B)$ and by region $(C)$ over the time period on the studied territory. Error bars represent \pm 1 standard error (see Figure 1 for regional boundaries and their numbering). 


\section{Figure 3}

Quantile plot of mean annual temperature and annual precipitation for the 216 observations, and annual temperature and precipitation averaged by year and by region.

Fig 3. Quantile plot of mean annual temperature and annual precipitation for the 216 observations ( $A$ ), and annual temperature (dots) and precipitation (bars) averaged by year (B) and by region (C), over the time period on the studied territory. Error bars represent \pm 1 standard error (see Figure 1 for regional boundaries and their numbering). 


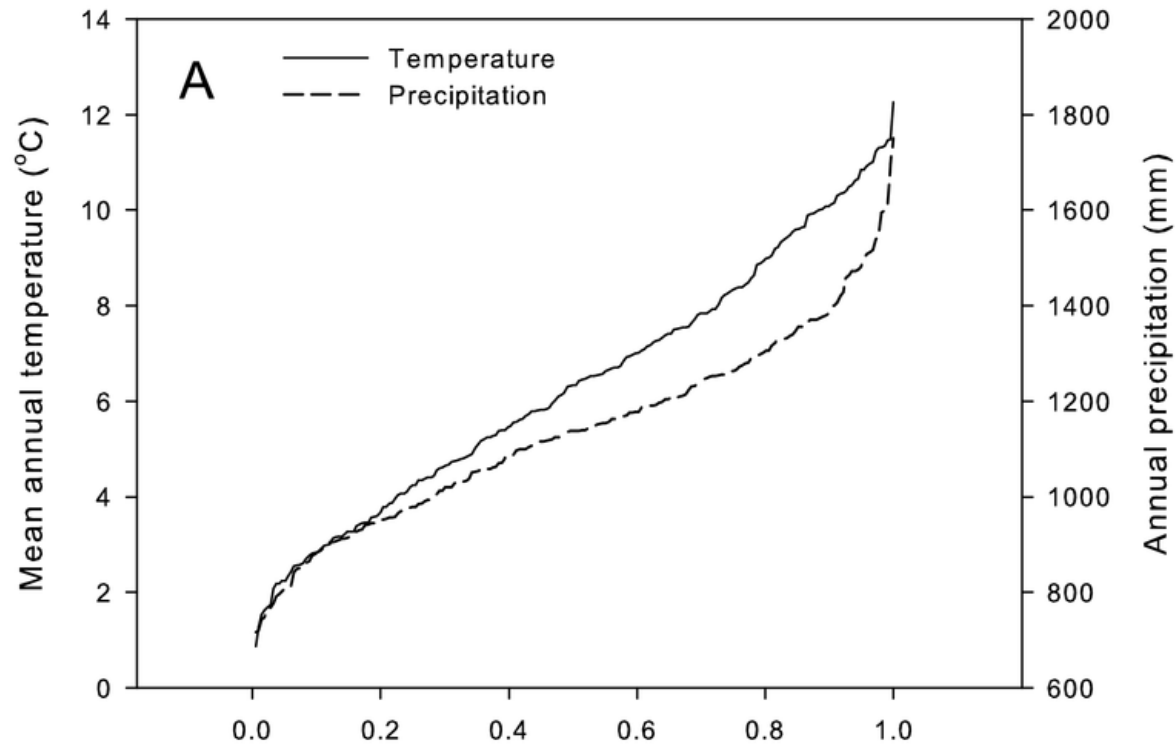

Fraction of observations
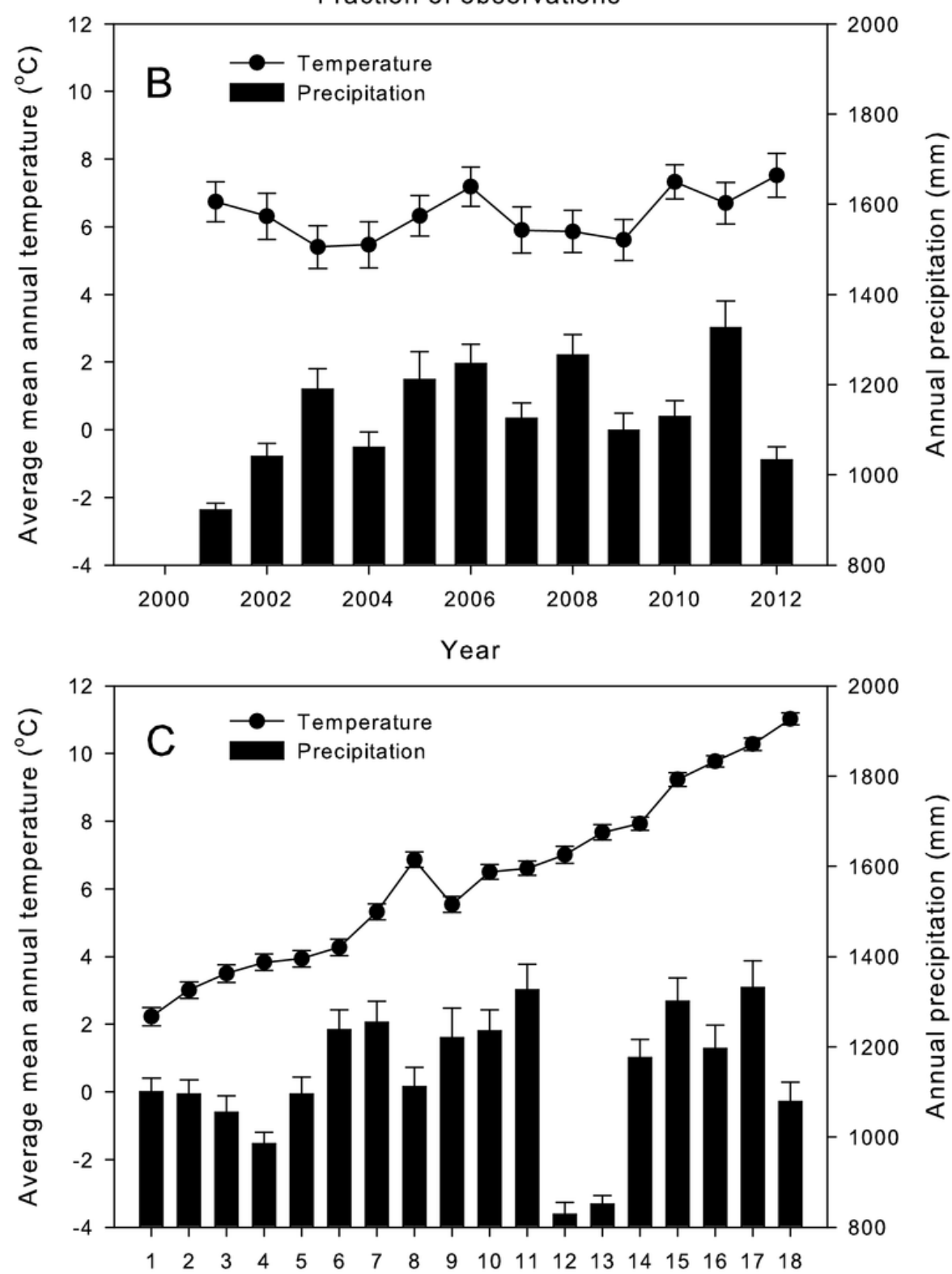


\section{Figure 4}

Observed and predicted yearly maple syrup yield at the regional scale.

Fig 4. Observed and predicted yearly maple syrup yield at the regional scale. The model explains $\left(R^{2}\right) 44.5 \%$ of the variance in maple syrup yield, with a mean absolute error of $61.8 \mathrm{ml} \mathrm{tap}^{-1}$ and a slight negative bias of $0.05 \mathrm{ml} \mathrm{tap}^{-1} .<$ ?xml:namespace prefix $=0 \mathrm{~ns}=$ "urn:schemas-microsoftcom:office:office" />

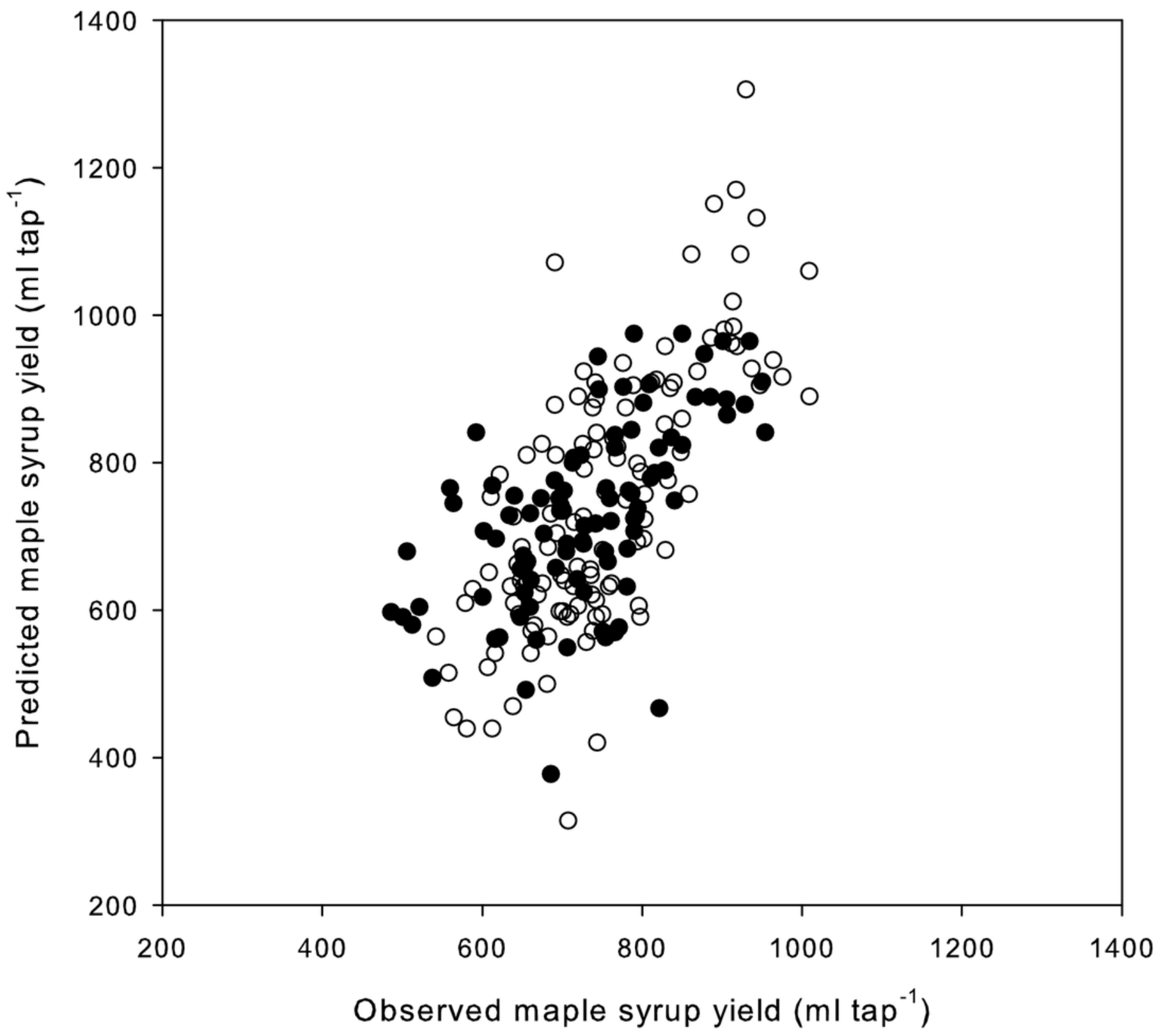




\section{Figure 5}

Partial regression residual plots summarising the effect of the selected climate variable on yearly regional maple syrup yield.

Together, these variables explain $44.5 \%$ of the variance in maple syrup yield with a mean absolute error of $61.8 \mathrm{ml} \mathrm{tap}^{-1}$. The variance inflation factors $(<$ or $=5.2)$ and condition indexes $(<$ or $=5.8)$ demonstrate the lack of problematic collinearity among independent variables. Parameter estimates along with their t-statistics and the associated probability $(P$ value) are provided for each variable included in the model. 

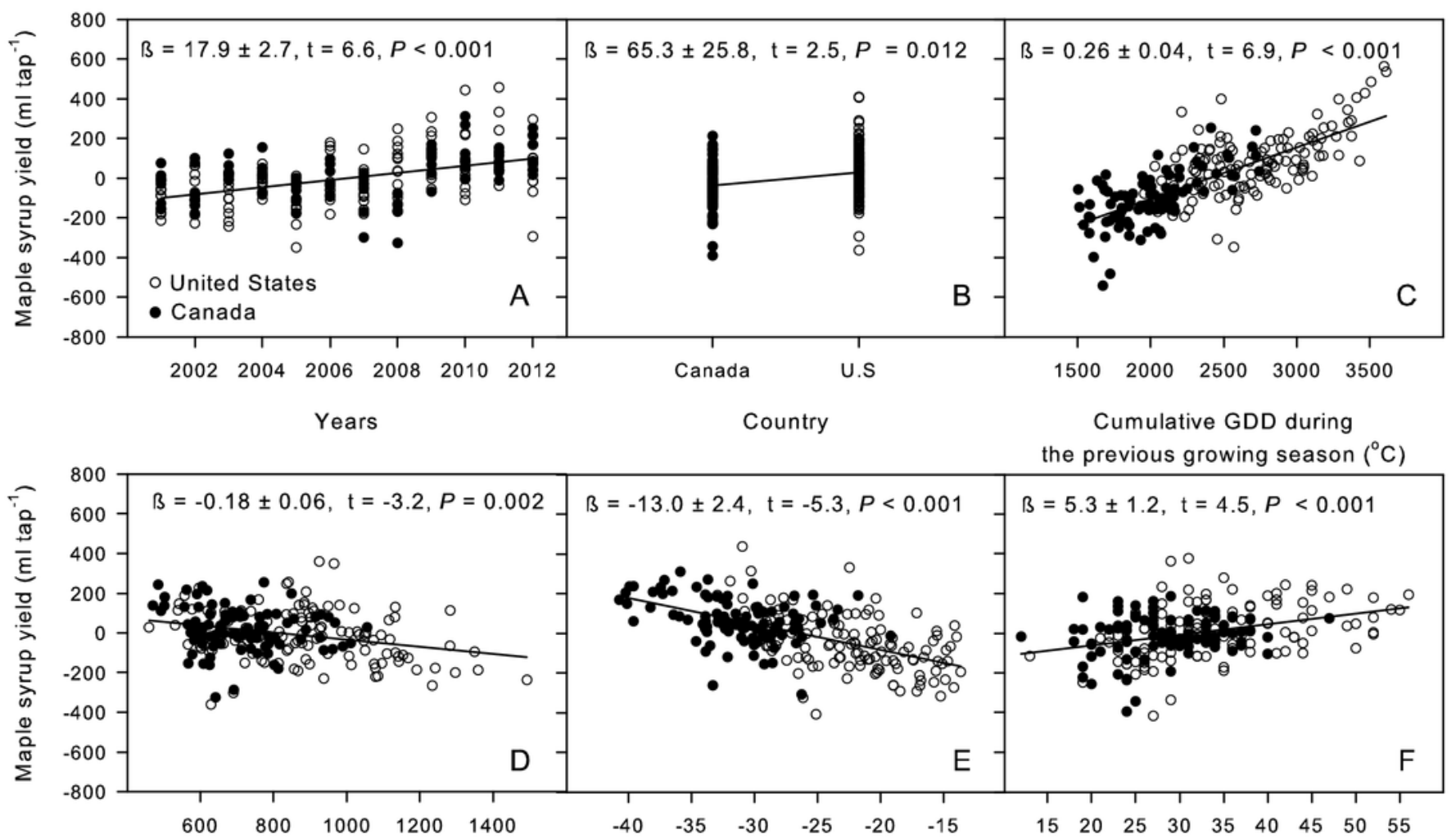

Cumulative precipitation over

Daily minimum temprature $\left({ }^{\circ} \mathrm{C}\right)$

Frequency of spring freeze-thaw events the previous growing season $(\mathrm{mm})$

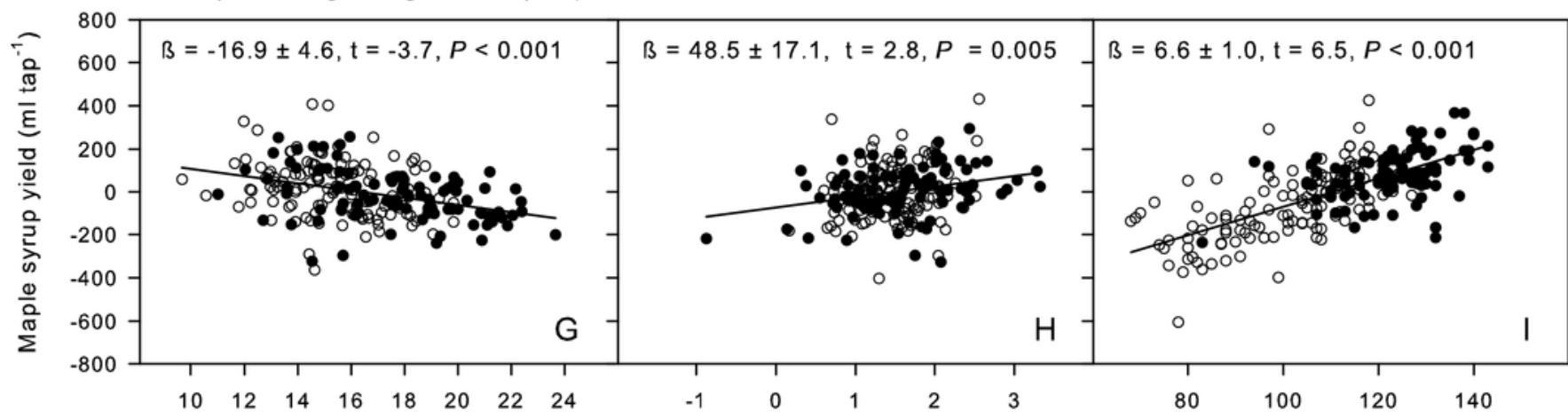

Maximum daily temperature during freeze-thaw events $\left({ }^{\circ} \mathrm{C}\right)$
Average daily mean temperature during freeze-thaw events $\left({ }^{\circ} \mathrm{C}\right)$
Day of year when the cumulative GDD reach 75 


\section{Figure 6}

Temporal evolution of the number of exploited taps in Quebec and the U.S. and of the residual of maple syrup yield, summarising the effect of time on yearly yield.

Fig 6. Temporal evolution of the number of exploited taps in Quebec and the U.S. (black circles) and of the residual of maple syrup yield (white circles), summarising the effect of time on yearly yield, while factoring out the influence of climate.

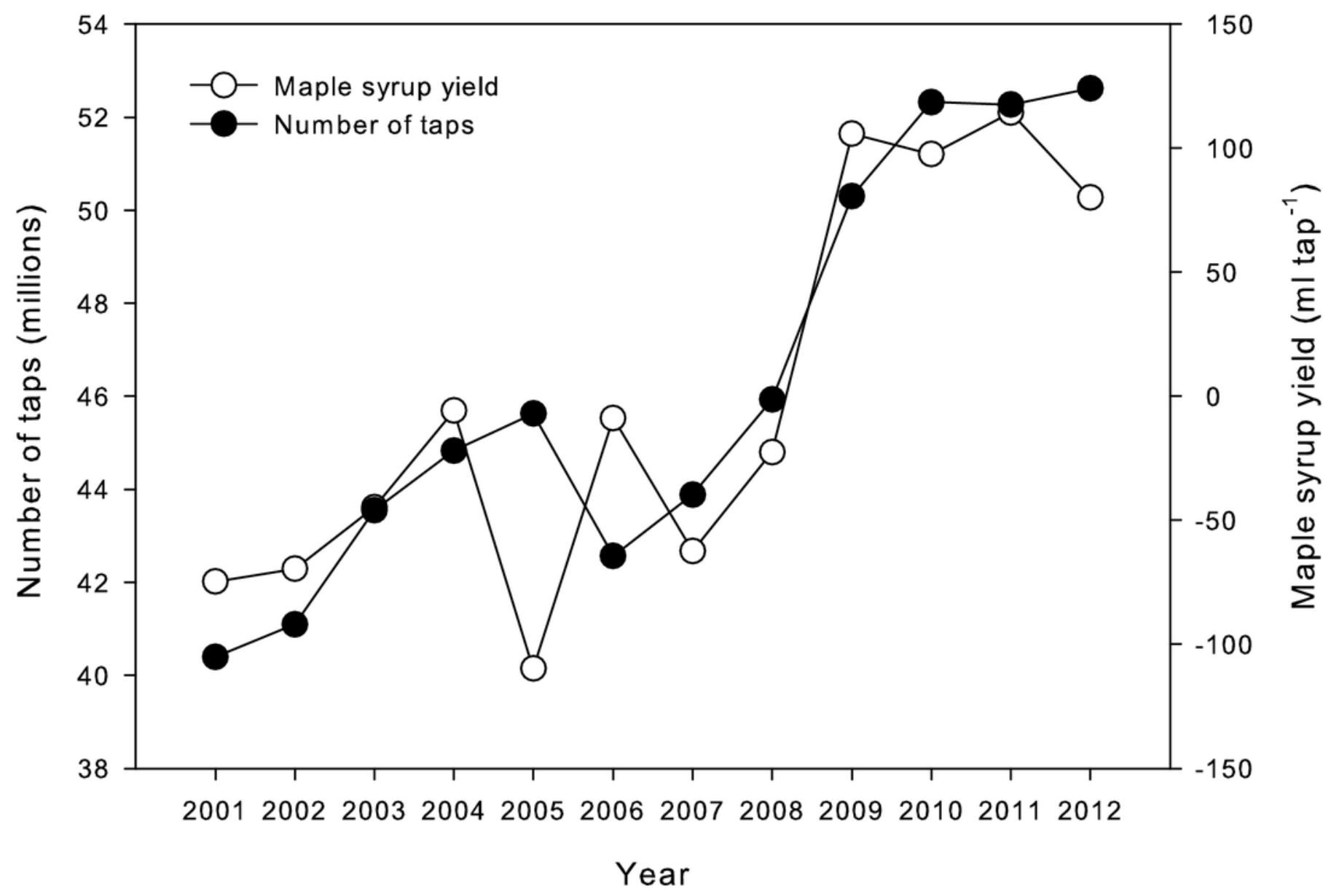

